\title{
Priming text function in personification allegory: a corpus-assisted approach
}

\section{Jacqueline Cordell}

Affiliation: University of Nottingham

Email: jacqueline.cordell@nottingham.ac.uk

\begin{abstract}
Current linguistic examination of allegory focuses on its cognitive structure as conceptual metaphor, with its linguistic form realised in the referential absence to a target domain (Crisp, 2001; 2008). The present study addresses the intersection of conceptualisation and form in examining how personification allegory functions within a literary context as either fictional world or thematic elements. Central to this is the idea of lexical priming, which suggests that readers are both textually and experientially primed to interpret personified referents allegorically or non-allegorically depending on their contextual use.

In this article I draw on Mahlberg and McIntyre's (2011) framework for literary text function to take an integrated cognitive-corpus-approach to exploring allegorical function through the lens of lexical priming, with corpus analysis revealing the patterns on which these cognitive primings are textually based. To this end, real-world examples of personification allegory are drawn from the Middle English allegorical poem Piers Plowman relative to a corpus of other late medieval poetic literature. My main findings suggest that the textual functionality attributed to allegorical referents is not mutually exclusive nor directly correlative to a particular textual pattern but rather contingent on the degree of animacy-based priming evidenced in their core semantic meaning or textual foregrounding. These results additionally indicate that function-based primings depend on the type of allegory appearing in the text (i.e., property versus class allegory).
\end{abstract}

\section{Key words}

Allegory, text function, lexical priming, corpus stylistics, Piers Plowman

\section{Author bibliography}

Jacqueline Cordell is currently a PhD researcher at the University of Nottingham. Her thesis looks at stylistic approaches to Middle English literature using corpus methods, and she works as a part-time lecturer in English Language at De Montfort University. 


\section{Introduction: allegory and textual function}

Once under the general purview of critical text studies allegory has increasingly become a topic of interest in linguistics, particularly from a cognitive perspective. Allegory has been shown to operate as an extended form of conceptual metaphor unique in its lack of explicit reference to a target domain, leading to 'an especially radical and indirect form of pragmatic inference' (Crisp, 2001: 9). This reliance on source-related language contributes to its low grading on Stockwell's $(1992,2002)$ and Sullivan's (2014) scales of metaphor visibility suggesting the high amounts of cognitive effort required for its interpretation compared to other metaphoric language. Allegory can identify individual texts or groups of text-types ${ }^{1}$ in which this feature characteristically occurs but in the present investigation the term exclusively refers to the linguistic construct, or linguistic allegory. Linguistic allegory is primarily comprised of two rhetorical techniques, personification and projection. Personification refers to the grammatical encoding of a noun or other part of speech's transformation into a proper name (Griffiths, 1985: 5), with prototypical examples using abstract nouns to embody ideological concepts or properties (i.e., Truth and Reason). By contrast, projection involves little grammatical change indicating that content should be read allegorically, thus requiring active readings of figurative significance based on relevant contextual knowledge brought to the text by the reader. Projection can apply to persons (i.e., historical or biblical figures) but also extends to locations and structural edifies in architectural allegory (see Whitehead 2003, Clarke 2008). Personification and projection in this sense broadly align with Halliday and Matthiessen's (2014: 676) grammatical metaphor versus ideational projection, and additionally correlate with the distinction between compositional and interpretative allegory described in medieval studies by Whitman (1987: 4-5):

Unlike the philosophic method of interpretative allegory, compositional allegory is essentially a grammatical or rhetorical technique. In its most striking form, it personifies abstract concepts and fashions a narrative around them... While interpretative allegory moves, for instance, from the fictional Athena to the underlying meaning of 'wisdom', compositional allegory begins with 'wisdom' itself, and constructs a fiction around it. 
To this end linguistic allegory has an acute performative potential 'either when encoded within the work itself or when projected onto it from the cultural archive of the medieval or modern reader' (Gillespie, 2008: 231-2). The latter (projection) has been the source of recent interest for cognitive linguists exploring the processes of interpretation involved when allegory is pragmatically rather than grammatically signalled, including Crisp's (2008) study of Blake through conceptual blending (Fauconnier and Turner, 2002).

The present study focuses on personification allegory. This concentration is linked to the grammatical encoding present in the language of the text absent in projection, with personification a process visible in the lexico-grammatical patterns underlying its textual use. This is not to say that personification does not integrate cognitive schemas or models (Gavins, 2007: 3-5) produced by the reader but rather that projection is less strongly encoded textually through markers including, for example, the capitalisation of personified entities. Approaching personification allegory also requires the further distinction between 'personification' and 'allegory' highlighted by Stanley (2008: 21) observing that while all instances of personification are metaphorical, they are not all allegorical. Allegory meaning is not automatically attributed to personification but rather only to instances imbued with additional evaluative meaning (i.e., political, ethical, religious, or moral) than generally ascribed to the given entity; the figure of Summer in the Middle English poem The Owl and the Nightingale, for example, is bestowed with moral signification not typically associated with the season as a temporal event.

One unusual aspect of personification allegory lies in its textual functionality. A systematicfunctional rather than a cognitive approach to language (e.g. Halliday and Matthiessen, 2014) functionality identifies communication as the primary purpose of language use but also addresses narrower context-dependent functions, or text functions. The functions of these words - or combinations or words - can be unique to a specific text or group of texts (Mahlberg, 2007: 4), or apply more broadly to a set of text-types. Mahlberg and McIntyre (2011) offer a classification system for text functions in literary discourse that separates words into 'fictional world' and 'thematic' 
functions. Fictional world terms constitute the concrete words that develop a text's fictional word, a concept not unlike the world-building elements in text-world theory (Gavins, 2007: 36-8). These terms establish the text world's setting physically, temporally, and spatially, and additionally convey information about the fictional characters appearing (and events taking place) in said fictional world. Thematic words, by contrast, are less concrete in that they retain additional thematic significance to a text beyond their core denotational meaning. Mahlberg and McIntyre (2011: 209) point towards gambler as a thematic term that, in a novel such as lan Fleming's Casino Royale, ostensibly exists as part of an extended theme in the text beyond identifying individuals characterised by participation in gambling-related activity.

Within this literary-based framework of text function most polysemous language including metaphor would be categorised as being thematic, however personification allegory is not quite so clearly defined on a functional basis. It possesses a world-building function in its use as a proper noun identifying a fictional character by name (i.e., Truth) but also operates thematically in the perpetuation of the broader ideological concepts imbued in the properties being personified (for example, themes of truth within a literary text oriented around moral approaches to daily life). In other words, personification allegory is pragmatically understood to be thematic but possesses a distinct fictional word text function in its grammatical encoding not evident in other types of metaphoric language. This does not necessarily indicate underlying problems with the framework itself but rather highlights a functional complexity and atypicality characteristic of allegory that warrants further investigation.

The present study aims to more closely examine the dual text functionality embedded in personification allegory through the lens of lexical priming (Hoey 2004; 2005) in an integrated cognitive-corpus approach. I first introduce lexical priming and how corpus methods actualise the priming of function at the textual level, then conduct initial concordance analysis of examples of personification allegory extracted from the medieval literary corpora used in the investigation. Drawing from select examples in the corpus analysis I demonstrate how allegorical text function is 
based on functional foregrounding, with the priming of one function over the other determinant on the degrees of strength attributed to each function via the amounts of animacy embedded in the allegorical referent and the patterns surrounding its textual use. My use of this dual cognitive-corpus approach is complementary, with corpus analysis revealing the patterns on which these cognitive primings are textually based.

To explore these text functions the study draws on the allegorical data contained in the late $14^{\text {th }}$ century Middle English narrative poem Piers Plowman (hereafter, PP). An approximately 7,000line text attributed to William Langland, $P P$ appears within a tradition of medieval poetry containing allegory including Pearl, The Book of the Duchess, and the translated Romance of the Rose. PP was chosen based on the volume of personification allegory present in the poem (Scanlon, 2007: 2) which provides a good survey of examples on which to conduct detailed examination of the features and patterns associated with the text functions of allegory within a literary context. This study is based on the C-text of the poem, the chronologically final of three identified authorial versions manifested in an interconnected network of over 50 surviving manuscripts. I follow Langlandian scholarship in using the text from the $X$ manuscript (Huntington Library MS 143) as the identified archetype of this C-text ${ }^{2}$.

\section{A corpus approach to personification allegory}

This critical focus on the interface between recurring textual patterns and resulting pragmatic inference in personification allegory is informed by theories of lexical priming. Lexical priming (Hoey, 2005: 13) postulates that individuals are experientially 'primed' to expect words to exhibit a preference to be used alongside other words (collocation), as well as within certain grammatical constructs (colligation). These linguistic preferences are expressed with degrees of affinity denoting the strength - and thus, likelihood - of a word appearing proximal to other textual features. When applied to the metaphoric language in allegory, lexical priming offers insight into the ways in which the immediate context of an allegorical term can be used to prime readers to interpret the construct 
as being more literal (i.e., the name of a specific fictional character) or more figurative as an ideological property along a cline of readerly interpretation.

Corpus linguistic methods assist in identifying the linguistic preferences underlying the priming of allegorical meaning by providing a decontextualised view of language use within a corpus, or set of digitised text. Central to this is the idea of concordance analysis, wherein focus can be narrowed to the use of a specific word (or set of words) as embedded within its immediate linguistic environment. This view enables observation of recurring lexical and grammatical patterns appearing to the left or right $(L / R)$ of the node word in a designated lexical window of occurrence. Programs such as WordSmith Tools (Scott 2012) have the capacity to produce these concordances, which can be used to analyse examples of personification allegory for information regarding the expression of its textual functionality.

One of the difficulties raised by a corpus approach to allegory is identifying textual examples within the corpus for concordance analysis. The capitalisation of non-syntactically initial terms in poetic verse can signpost personification allegory, however this feature is not always guaranteed even in modern editions of medieval literature. Allegorical identification instead relies on its worldbuilding function as the name of a fictional character in the text, with the proper nouns denoting character names typically featuring as the top content words in keyword lists generated for fictional texts (Mahlberg and McIntyre 2011: 207). Keywords, when defined quantitatively, are words that appear with unusual frequency in a corpus when compared to another text or reference corpus, with frequency assessed statistically rather than via raw frequency of occurrence (Culpeper and Demmen, 2015: 92-4). Given that keywords are 'key' in that they reflect what the text is about and fundamental concepts associated with that particular work (Scott and Tribble, 2006: 55-6), it would not be unexpected to find the names of allegorical characters contained in corpus-generated keyword listings.

To generate these keywords PP was compared to the Middle English Poetic Literary Corpus (MEPoetLitCorp), a self-built reference corpus containing 28 late Middle English poetic texts 
composed in the late $14^{\text {th }}$ and early $15^{\text {th }}$ centuries. This reference corpus features a sampling of literature contemporary to $P P$ drawn from open-access databases including the Corpus of Middle English Prose and Verse (CMEPV), the Oxford Text Archive (OTA), and the University of Rochester's Middle English Text Series (METS). The 890,778 words constituting MEPoetLitCorp - featuring texts written by Chaucer, Gower, the Pearl Poet, and some anonymous sources - provides a point of departure for identifying the comparatively significant keywords appearing within the 70,541 words in the text of $P P(P P C o r p)$.

Figure 1: The 28 source-texts for MEPoetLitCorp listed alphabetically by title.

\begin{tabular}{ll}
\hline The alliterative Morte Arthure & $\begin{array}{l}\text { The Parlement of the Thre Ages } \\
\text { Patience }\end{array}$ \\
Anelida and Arcite & Pearl \\
The Awntyrs of Arthure & Pierce the Ploughman's Crede \\
The Book of the Duchess & The Pistel of Swete Susan \\
The Canterbury Tales & The Plowman's Tale \\
Cleanness (Purity) & Richard the Redeless \\
Confessio Amantis & The Romance of the Rose \\
The Destruction of Troy & Saint Erkenwald \\
Gologras and Gawain & The Siege of Jerusalem \\
The House of Fame & Sir Gawain and the Green Knight \\
Joseph of Arimathie & Troilus and Criseyde \\
The Legend of Good Women & The Wars of Alexander (Fragment C) \\
Mum and the Sothsegger & Wynnere and Wastoure \\
The Parlement of Foules &
\end{tabular}

This approach situates the present investigation within other corpus stylistic keyword studies using specialised literary reference corpora including but not limited to Scott's (2009) comparison of Romeo and Juliet to other Shakespearian plays, and Fischer-Starke's (2009) study comparing Pride and Prejudice to other Jane Austen novels as well as a selection of $18^{\text {th }}$ and $19^{\text {th }}$ century novels. The current focus on Middle English poetry here addresses much earlier literature than generally explored in corpus stylistics, with the onus of current research oriented around the Early-Modern English of Shakespeare and his contemporaries.

To account for the spelling variation present in these Middle English texts both PPCorp and MEPoetLitCorp were orthographically annotated prior to corpus analysis. I used the tool Variant 
Detector (VARD) to manually train the programme on 32,000 words selected at random across both corpora, then used the trained version of VARD to automatically regularise the rest of the corpus data. This regularisation occurred by taking the Middle English variants and replacing them with their standardised Modern English forms. While this approach did not result in the degree of spelling regularisation taken for granted in modern language corpora, it enabled corpus analysis to be performed using data evidencing less spelling variation than the original poetic texts. It does result in a mixture of Modern and Middle English forms within the annotated versions of the corpora, which is likely to have had an impact on the resulting keyword data. However, this study's focus on highly key terms such as character names increases the likelihood that these targeted terms would still appear in keyword lists generated for PPCorp, even if said keyness value was divided amongst several different lexical entries ${ }^{3}$.

Figure 2 identifies the 45 personification-based allegorical keywords for $P P$. These results were generated by comparing the language of PPCorp to MEPoetLitCorp in WordSmith using a pvalue of .0001 , then selecting the character names occurring in the keyword list. This listing does not contain all the personification allegory present in the poem but rather terms exhibiting unusual recurrence in $P P$ relative to the reference corpus texts. Given the present focus on personification conventional fictional characters (Piers, Perkin) and biblical figures (Adam, Eve, Jesus, Abraham) embodying examples of allegorical projection were not included.

Figure 2: The 45 instances of personification allegory revealed in the 855 total keywords generated for PPCorp, listed in order of descending keyness value ${ }^{4}$.

\begin{tabular}{rrrrrr}
\multicolumn{1}{c}{ N } & Key word & Keyness & \multicolumn{1}{c}{ N } & \multicolumn{1}{c}{ Key word } & Keyness \\
\hline 12 & CONSCIENCE & 495.41 & 175 & DOCTOR & 43.66 \\
17 & MEDE & 337.97 & 205 & CONTRICIOUN & 40.63 \\
18 & DOWEL & 318.45 & 221 & LECHERY & 36.72 \\
20 & HOLY & 301.59 & 244 & REAVE & 33.87 \\
21 & CHURCH & 299.99 & 285 & FAITH & 31.11 \\
24 & KIND & 271.23 & 299 & LORD & 28.42 \\
37 & POVERTY & 160.22 & 303 & JUSTICE & 27.76 \\
41 & TRUTH & 152.67 & 317 & SLOTH & 26.52 \\
45 & REASON & 143.00 & 363 & CONSEYL & 25.73 \\
49 & DOBET & 135.72 & 368 & FALSE & 25.35 \\
54 & MERCY & 121.40 & 382 & GLUTTON & 23.55
\end{tabular}




$\begin{array}{rrrrrr}57 & \text { PATIENCE } & 118.61 & 410 & \text { BREWER } & 20.88 \\ 70 & \text { DOBEST } & 99.18 & 411 & \text { PASTOR } & 20.88 \\ 71 & \text { PEES } & 98.64 & 413 & \text { NEIGHBOR } & 20.88 \\ 83 & \text { CHARITY } & 80.97 & 462 & \text { IUSTUS } & 20.88 \\ 90 & \text { HUNGER } & 75.26 & 463 & \text { HAYWARD } & 20.88 \\ 95 & \text { GUILE } & 70.07 & 519 & \text { PRIDE } & 18.93 \\ 102 & \text { GRACE } & 66.67 & 531 & \text { SURGEON } & 18.03 \\ 119 & \text { REPENTANCE } & 57.93 & 584 & \text { SIMONYE } & 16.03 \\ 138 & \text { FRIAR } & 51.32 & 593 & \text { TREUTH } & 15.97 \\ 145 & \text { SYMONYE } & 50.69 & 617 & \text { WYDDORE } & 15.66 \\ 152 & \text { WIT } & 48.53 & & & \\ 159 & \text { CONTRITION } & 46.98 & & & \end{array}$

As evidenced above, the majority of the text's personification allegory appear in the top third of the keyword list for PPCorp. Several terms situated outside this clustering include spelling variants not addressed in the regularisation process identifying allegorical figures already featured in existing lexical entries such as contricioun 'contrition', simonye 'simony', and iustus 'justice'.

These keyword results reveal the different types of personification allegory appearing in the poem. Overall the keywords illustrate a heavy textual emphasis on abstract nouns, including virtues (conscience, truth, reason, patience), vices (sloth, glutton 'gluttony', pride, lechery), legal concepts (mercy, justice, simony), emotional states (repentance, contrition), and states of existence both literal (poverty, hunger) and metaphorical (grace) - or possibly both (pees 'peace'). These examples are illustrative of property allegory, wherein mental properties or ideological concepts are used in the construction of a personified allegorical figure (Crisp, 2001: 13-4). Property-based personification allegory presents a fictional character 'whose salient characteristic is that property' (Turner, 1987: 21-2), with its evaluative potential based on being correlative to the given property; to this end, virtually all characters are endowed with characteristics aligning with that of the property or ideological concept they represent. Truth, for example, would not be presented as an individual inclined towards dishonesty and inaccuracy but rather consistently characterised by clarity of vision and honest intentions.

Property allegory also occurs within allegorical constructs spanning across multiple keyword entries. Examples of these include holy and church 'Holy Church' referring to the personified version 
of the ideologies of, or teachings perpetuated by, a religious institution (rather than, for example, a locationally identifiable structural edifice). This also occurs in $P P$ through the combination kind and wit 'Kind Wit' as the idea of naturally-derived reasoning which, from a medieval worldview, refers to the inborn mental capacity to distinguish between right and wrong and to guide one's conduct accordingly (MED). The use of this faculty was thought to produce a sense of natural wisdom standing in opposition to cognitive processes fuelled by either divine revelation or learned types of logical reasoning; White (1988: 3-5) discusses a number of modern equivalents for this concept offered by medievalists, including 'practical' or 'natural reasoning', 'native intelligence', and even 'common sense'. These allegorical referents are occasionally comprised of a single term (i.e., Kinde), which accounts for one of several possible reasons for the different keyness values attributed each word separately in the corpus data.

Figure 2 also includes property allegory manifested in proper nouns comprised of imperative verbal phrases. These phrases are constructed from the co-occurrence of the main verb do with the declarative, comparative, and superlative forms of good in dowel 'do well', dobet 'do better', and dobet 'do best'. The shift from personification via (largely abstract) nouns to verbal phrases extends allegorical significance from the ideologies themselves to the physical actions inspired by these underlying properties as existential goals, as illustrated in (i):

(i) Thus y-robed in russet y romede a-boute Alle a somur seson for to seke dowel And fraynede ful ofte of folke pat y mette yf eny wiht wiste where dowel was at ynne And what man amyhte be of mony men y askede ( $P P, 10: 1-5)$

Thus robed in russet I roamed about All of a summer season to seek Do Well And often asked of folk that I met If anyone knew where Do Well dwelled And what kind of man he might be I asked of many men.

The keyword list for PP moreover contains instances of class allegory. As defined by Crisp (2001: 14) class allegory constitutes the personification of a demographic or socially-constructed group of persons as a single entity through grammatically singular common nouns. While similar to 
collective nouns like clergy and community, class allegory is different in that it directly identifies an unnamed character via a characteristic feature ascribed to the person instead of through a given name. Examples of these are found dispersed throughout the keyword list for PPCorp, with the majority of terms demarcating persons via their professions such as friar, doctor, reave 'reeve', conseyl 'counsel', brewer, pastor, hayward, 'overseer', and surgeon. Class allegory in PP extends beyond profession-based representation to social positions (lord) and marital status (widower) as well as referential descriptions of persons through communally-expressed social relationships (neighbour). Most of the characteristics chosen for class-based allegorical identification in PP are predicated on existing stereotypes possessing strong evaluative connotations including, among others, the overwhelmingly negative representations of the slovenly and corrupt brewer in medieval literary and legal discourse (see Bennett 1996).

The rest of the study draws on the data in Figure 2 to explore the textual patterns of use underlying personification allegory's fiction world and thematic functions, and moreover how these are textually primed. Initial concordance analysis was conducted on all keywords, with the present discussion highlighting recurring patterns evidenced across the keyword data as exemplified in two of the text's allegorical constructs, kind wit and friar ${ }^{5}$.

\section{Textual manifestations of allegory: kind wit and friar}

The majority of the textual patterns surrounding property-based personification allegory in $P P$ involve colligation with main verbs. As exemplified in below in Figure 3, this verbal colligation primarily situates the allegorical construct (in this case, $k i n d$ wit) as the grammatical subject alongside verbs denoting physical movement as in came kind wit $(9,10)$, or through verbs conveying cognitive actions either referencing shared knowledge or instruction $(8,13)$ or signposting dialogic speech as seen with kenned 'told' (6) tells (11), said (22), and carpe 'says' (16). Given the freer syntactic structure of Middle English these verbal colligations typically appear in the R2 position to the allegorical referent within the syntactic ordering SUBJECT + OBJECT + VERB, as evidenced in kind 
wit me taught 'as kind wit taught me' (13) and kind wit hym taught '(as) kind wit taught him' (8). A smaller proportion of these verbal colligations feature these allegorical constructs as grammatical objects alongside verbs including, among others, have $(14,20)$ and find (12).

Another trend evidenced in the textual representation of personification allegory is its recurring appearance in binomial patterns. The coordination of two words or phrases through syntactic elements such as 'and' or 'or' (Bhatia, 1993: 108), binomials simultaneously involve collocation and colligation at the level of text based on the grammatical and semantic similarity shared by the two entities. These binomial patterns predominantly align $P P^{\prime}$ s property allegory with other abstract concepts, in this case illustrated with the coordination of kind wit to conscience $(4,6)$ and grace (5). Many binomials also link allegorical persons to collective nouns as demonstrated in Figure 3 with knyhthoed and knyghthed 'knighthood' $(9,4)$, catel 'livestock' $(3)$, clergy $(2,17)$, and community (13), with the recurring word-initial phonetic parallelism evidenced across the majority of these binomials reflective of $P P^{\prime}$ s status as text written in intra-linear alliterative verse.

Further concordance analysis also demonstrated repeated colligation with definite articles and possessive pronouns. As with virtually all the property allegory in Figure 2 kind wit appears proximal to pronominal possessors such as his in the L1 position (15) in the patterning POSSESSIVE DETERMINATIVE + kind wit, though not to the same degree of representativeness demonstrated in the other allegorical keywords (for example, reason and mercy). This co-occurring L1 pattern is also observable for definite articles (21) however this affinity to grammatical definiteness is far more prevalent in the poem's class allegory, as evidenced in the concordance lines for friar illustrated in Figure 4. As indicated below, the term appears 15 out of 34 times in PPCorp proximal to markers of definiteness including the definite article in the friar (21-31) and the demonstratives in that friar (19, $20)$ and this friar $(32,33)$. This amount of definite grammatical colligation corresponds to the percentages evidenced in the other class allegory in PP, with approximately equal comparative L1 colligation with indefinite premodifiers occurring in a friar (1-7), some friar (18), any friar (9), no friar (16), and one friar (17). 
Figure 3: Concordance of the 22 total instances of kind wit in PPCorp, organised alphabetically by L1 position.

1 for-thy said Piers Harrowed all the that able kind wit by counsel of doctors And tills after here te 2 we bid ever Ac clergy comes both of sight and kind wit of stars As to be bore or by-gete in such a c 3 in Beacius est dare quam petere $A_{c}$ cattle and kind wit acombreth fool many wo is him that hem weldet 4 t potentes de seed \& cetera ?if knyhthoed and kind wit and the community and conscience Together pra 5 ibus celestibus so grace is a gift of god and kind wit a chance And clergy a cunning of kind wits te yndely as clerk doth his books Conscience and kind wit kenned me to his place And made me sykereness r ri?tfulliche reason should rule ?ow all And kind wit be wardeyn ?our wealth to keep And tutor of ? all kin crafts His cokeres and his coffes as kind wit him taught And imprisoned his hopur on his ha ght of tho men made him to reign And then cam kind wit and knighted together Caste that the communit $\mathrm{n}$ pride butte grace were with vs And then cam kind wit Conscience to teach And cried and commanded a of friars For they said Conscience by Christ kind wit me tells Hit is wikked to wage ?ow ?e grows o Caste that the community should here to find kind wit and the community contrived all crafts And fo s sonnest yblamed In Conscience know this for kind wit me taught That reason shall reign and tides g that seek after the whyes How creatures have kind wit and how clerks come to books And how the flow tted man but clerks him teach come for al his kind wit through christendom to be saved The which the ou praise and believe al thy life time And if kind wit carpe here-a?en or any kind thoughts or ereti e him then cares heneuer Nor of clergy nor of kind wit counts he not a rusche To blame him or to bea Adam and Eve and all other beasts A cantel of kind wit here kind to save of good and of wykke kind w nde for christs love more Then any conning of kind wit but clergi hit rule For moyses witnesses that knew hit There nor ws christian creature that kind wit had That he nor halpe a quatite quantity holi e by our lord a lip of gods grace Then al the kind wit that ?e can both and kunnyng of ?our books Fo labour to live while life on land lasts Then kind wit to the king and to the community said Christ 
Figure 4: Concordance of the 34 total instances of friar in PPCorp, organised alphabetically by L1 position (first 5 omitted for purposes of space).

$\mathbf{N}$

Concordance

ind Then come there a confessor dressed as a

nyel the does playere and denote the bautde And

easts Ibunt magi ab Orient \& cetera Frer if any

0 ng Ouh said y tho and my head shook By my faith

11 us est mori quam male viuere $y$ read no faithful

es men be waer and wysly hem keep that no false

that lady laughing said $Y$ shall be ?our friend se him for moes and for leaves Fowls him fed if ing and at the last they aspyde That faytede in for truth Would y never further no foet for no re of physic by fer and fayror he plastered one e never By so you rich were confess the to some we be diverse clothed Ac y wiste never man that 11 suffer said Conscience sanes ?e desiren That her other Thus through noble speech entered the s a-dreint said pees and so doth many other The speech heet pees tho opene the ?ates Let in the aterare be accomplished and physic ?ow seek The hard is if they keuere $y$ am a surgeon said the $e$ and put me to be lowe And flitting fond $y$ the ns on the day By aforbisene said .er..Piers the that sit within the board so hit fares said the oevil where they dwell both truthfully said the isse the people y shall say the my son said the gods And then louhe truth for y scowled on the why scowl said truth leave sire y said For this e eschete what his will were In faith said this left they lordship both land and undisciplined friar To mede the maid kindly he said You ignorant $m$ friar lying And both the first friend be lies leave friar faytour and folk of that order That lollards a friar we found there $y$ ?eve the five shillynges Nor friar said y you fare like the miserable that wish $\mathrm{n}$ friar at thy feast to sit ?ut were me lever by our 1 friar through flaterynge hem bygyle Ac me thinks loa friar and fail ?ow never The whiles ?e praised this friar Austynes be true For he ordained that order or friar clothinge had fat cheeks For-thy l.oft they he friar prechynge ?us said Perus the ploughman and pok friar flatterer is fiscicien and surgeon Said contri friar he shall absolve thus soon How so ever you wis friar is y-cald of the five mendynantz that took thi friar flaterare be accomplished and physic ?ow seek friar And cam to Conscience and corteylich corteysli friar with his physic this folk hath enchanted And a friar and his felawe and make hem fayere face He may friar hereof heard and hyede fast to a lord for a le friar and salves can make Conscience knows me well a friar that me confessed And said he might not me abs friar y shall the fair show Let bring a man in a poe friar by the rightful mannus falling You he through friar a sojourned with vs friars And ever hath as y friar then How seven sithes the sad man sins on the friar why scowl said truth leave sire y said For thi friar flattered me the while he fond me rich And now friar for profyt and for health Karpe $\mathrm{y}$ would with $\mathrm{C}$ Friar franciscan and dominican for love to be holy A 
A cumulative survey of these underlying textual patterns, exemplified in the concordances for kind wit and friar, suggest that interpreting personification allegory is determinant on generated perceptions of agency. This agency is manifested in patterns signposting personhood, with personified characters attributed with agency through the performance of their own independent actions, thoughts, and even dialogue (Yamamoto, 1999: 10; see also Yamamoto, 2006). In this sense the verbal colligation observed in kind wit (and, by extension, in most of the poem's property allegory) act as 'carriers of personifying metaphor' (Leech and Short, 1981: 198-9) which prime the application of an additional level of allegorical personhood to the given property. This additional agency produces inferential meaning beyond what is typically expected of abstract concepts that facilitates its pragmatic interpretation as an allegorical character. To this end, agency operates as a generated effect which primes the textual functionality of kind wit as a world-building element in the text, a process illustrated in Figure 5.

As such, it is the absence of primed agency that results in the production of a less distinct fictional world text function. The agency embedded in the kind wit's verbal colligations is not evident in its colligation to possessive pronouns exemplified in the phrase his kind wit, signalling that the additional pragmatic layer of personhood is not meant to be imposed on the term's core denotational meaning. This absence of layered inferential meaning instead primes a reading of the concept as the property of natural reasoning estranged from the allegorical significance embedded in more agency-based textual features. While possible for this POSSESSIVE DETERMINANT + kind wit patterning to indicate ownership of or a close relationship with another (in this case, allegorically constructed) person, this is not the case of virtually any of the examples wherein possessives cooccur with property allegory in $P P$. As a result, this specific pattern of use primes readings of kind wit as something to be possessed (or not) by people in general; to interpret these examples as allegorical referents to a fictional character rather than a thematic signal would be at odds with its underlying lexical priming. 
Figure 5: Hierarchical relationship illustrating the way in which textual patterns - and the lexical priming resulting from said features - produces text function in allegory, moving towards increasing levels of abstraction.

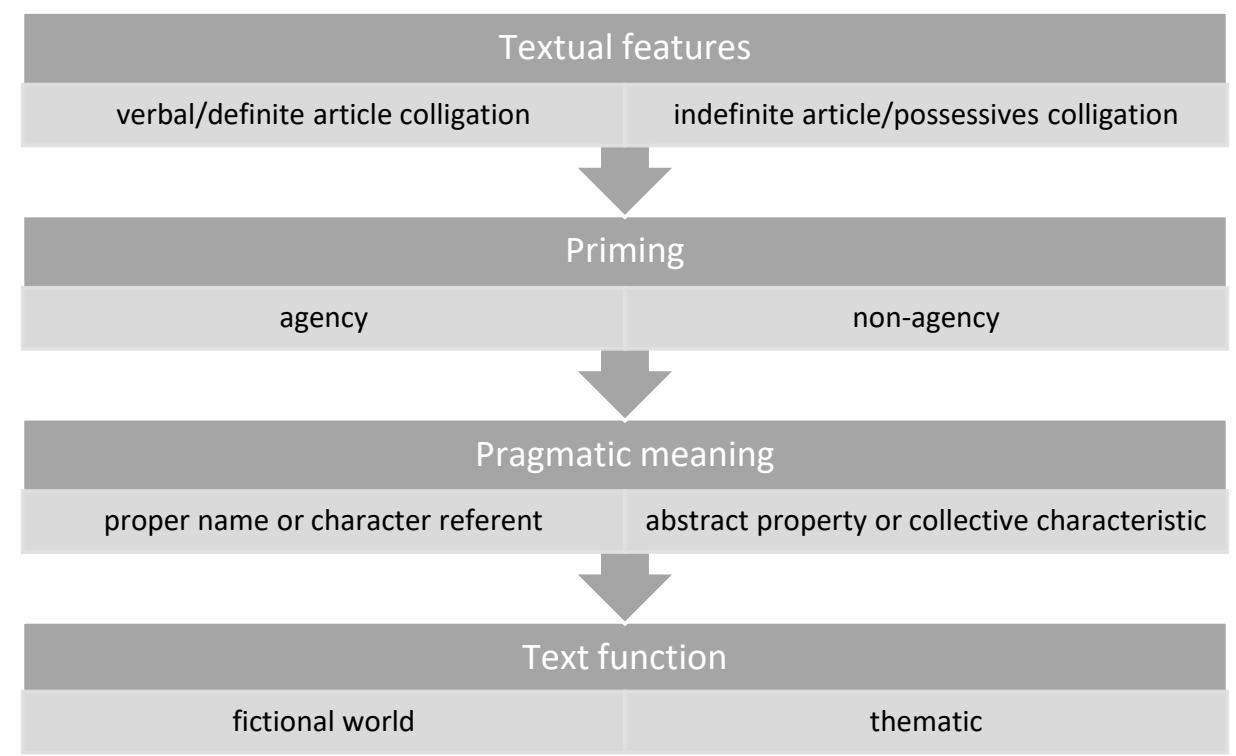

Despite the neatness of the analytical levels represented in Figure 5, this binary divide between fictional world and thematic priming is an artificial construct from a cognitive perspective. In addition to problems associated with reading instances of allegory too literally at the expense of its thematic significance (i.e., reading $P P$ as being about a succession of dreams containing some very oddly-named characters) it is also reasonable to assume that textual patterns conveying non-agency are likely coloured by the background knowledge that the term might refer to the allegorical character despite the lack of overt markers promoting a fictional world function. This is particularly applicable to $P P$ as a text operating within a larger allegorical literary tradition. The representation in Figure 5 is not meant to indicate that a dual understanding of a textual instance of personification allegory is impossible but rather that there are distinctive levels of textual and inferential processing that contribute to the interpretation of textual function in personification allegory.

\section{Animacy and degrees of allegorical priming}

How readers are primed to interpret degrees of allegorical function is fundamentally linked to animacy. A cognitive distinction between the animate and inanimate operating along a hierarchical 
gradient (Yamamoto, 1999: 149), animacy facilitates a generalised distinction between human entites and non-human concepts in allegorical constructs. It is the readerly perception of this animacy that underlies the search to explain the closeness experienced between reader and context in both Langacker's (1991: 305-29) empathy scale and Stockwell's (2009: 30) scale of attentional attractors in literary resonance. Both frameworks implicitly attribute the greatest amount of animacy to individual persons (i.e., an identified speaker or listener) identified in a text, followed by groups of people or indeterminate persons and gradually leading to animals, objects, and abstract entities possessing the weakest links to the reader, as well as the smallest amount of recognisable animation. In this sense animacy is the product of conveyed agency and definiteness combined along a cline of anthropomorphic specificity, with it being natural to cognitively 'ascribe a stronger sense of animacy to an entity who/which is highlighted or activated as an individual in our minds than to one which is a part of an indeterminate mass' (Yamamoto, 1999: 28, citing Comrie, 1989: $189)^{6}$. Studies such as Foley and Van Valin (1985: 288, cited in Yamamoto, 1999: 27) supplement these cognitive understandings of animacy by examining the methods by which degrees of animacy are linguistically encoded.

The juxtaposition of these cognitive and textual approaches to animacy in Figure 6 presents a model for exploring personification allegory as the priming of varying levels of expressed animacy. From this perspective the differences between $P P^{\prime}$ 's property and class allegory are visible based on different levels of semantic animacy embedded in the allegorical referents themselves. Class allegory is already encoded with some animacy in being an ill-defined human entity expressed by a common noun, while properties such as truth and reason contain virtually none in their representation of abstract entities via inanimate nouns. However, ideological properties being used allegorically contain much stronger expressions of animacy than class allegory as specific persons identified by proper nouns. 
Figure 6: Complementary theories reflecting animacy in language along a gradient of decreasing animacy from left to right, with [>] denoting sub-levels of animacy within each grouping.

\begin{tabular}{|c|c|c|c|c|c|c|}
\hline \multirow[t]{2}{*}{$\begin{array}{l}\text { Cognitive } \\
\text { animacy scale }\end{array}$} & $\begin{array}{l}\text { Langacker } \\
\text { (1991) }\end{array}$ & Speaker>hearer & Human & Animal & $\begin{array}{l}\text { Physical } \\
\text { object }\end{array}$ & $\begin{array}{l}\text { Abstract } \\
\text { Entity }\end{array}$ \\
\hline & $\begin{array}{l}\text { Stockwell } \\
\text { (2009) }\end{array}$ & $\begin{array}{l}\text { Specific } \\
\text { persons }\end{array}$ & $\begin{array}{l}\text { Ill-defined } \\
\text { individuals }>\text { groups }\end{array}$ & $\begin{array}{l}\text { Animals } \\
>\text { plants }\end{array}$ & $\begin{array}{l}\text { Machines> } \\
\text { immovable } \\
\text { objects }\end{array}$ & $\begin{array}{l}\text { Landscape } \\
\text { objects> } \\
\text { abstractions }\end{array}$ \\
\hline $\begin{array}{l}\text { Interpretative } \\
\text { animacy scale }\end{array}$ & & \multicolumn{3}{|c|}{$\begin{array}{l}\text { Agency (movement>speech>sentience; } \\
\text { definiteness) }\end{array}$} & \multicolumn{2}{|c|}{$\begin{array}{l}\text { Absence of agency } \\
\text { (indefiniteness>possession) }\end{array}$} \\
\hline $\begin{array}{l}\text { Linguistic } \\
\text { animacy scale }\end{array}$ & $\begin{array}{l}\text { Foley \& } \\
\text { Van Valin } \\
(1985)\end{array}$ & $\begin{array}{l}1^{\text {st }} \& 2^{\text {nd }} \\
\text { person }>3^{\text {rd }} \\
\text { person } \\
\text { pronouns }> \\
\text { proper nouns }\end{array}$ & $\begin{array}{l}\text { Human common } \\
\text { nouns }\end{array}$ & $\begin{array}{l}\text { Other } \\
\text { animate } \\
\text { nouns }\end{array}$ & \multicolumn{2}{|c|}{ Inanimate nouns } \\
\hline
\end{tabular}

One of the advantages offered by Figure 6 is its inclusion of an 'interpretative animacy scale' to represent the intermediary level situated between animacy's linguistic form and conceptual structure. This scale draws from the research conducted on PPCorp's allegorical keywords to highlight the role of agency not only as an aspect of cognitively primed animation but also as a literary effect generated from the underlying patterns in which these allegorical constructs are situated. This is of particular import for the poem's verbal allegory (dowel, dobest) which do not themselves contain encoded degrees of animacy within the paradigm set forth in Figure 6, but rather rely on the agency-based animacy generated from the patterns surrounding their textual use.

Applying interpretative animacy beyond semantic encoding to the textual features and patterns surrounding these allegorical referents reveals the comparative levels of thematic and fictional world priming operating within individualised examples of personification allegory. As mentioned previously, patterns like the verbal colligation associated with property allegory layer a fictional world function over an underlying thematic function. The strength of these functions relative to one another is based on the agency-based animacy contextually encoded in the different 
types of colligating verbs. For example, verbs such as 'come' and 'depart' convey more agency through physical motion than verbs denoting cognitive processes of thinking and knowing. These cognitive processes still convey agency to ideological properties such as kind wit though reference to sentience or even overt speech acts, but not to the same degree facilitated through colligation with motive verbs. The recurring use of taught similarly produces a fictional world function in its characterisation of the allegorical figure as an instructor in (ii) when Perkin states his intent to go on a pilgrimage:

(ii) And yshal parayle me quod Perkyn in pilgrimes wyse And wende with alle tho pat wolden lyue in treuthe And caste on hym his clothes of alle kyn craftes His cokeres and his coffes as kynde wit hym tauhte $(7)(P P, 8: 57-60)$

'And shall I apparel me in pilgrim's clothes', said Perkin

'And wander with all those who would live in truth

And cast on him his clothes of all kinds of crafts His trousers and his gloves, as Kind Wit taught him'.

Also observable in (13) in Figure 3, this patterning kind wit him taught does not increase the agency of the allegorical figure but it does increase its conceptual definiteness through the provision of additional description signalling the entity's uniqueness as an individual via an abstract professional role in an inferential process not unlike the recurring definiteness embedded in the poem's class allegory. In these cases the semantic meaning of kind wit is still present and able to be interpreted by the reader, but it is far more difficult to exclusively understand the term as referring to the idea of innate common sense. In other words, an exclusively thematic-based figurative reading is still possible, but more cognitively challenging.

The different strengths attributed to each text function suggests that allegorical meaning is based on the cognitive foregrounding of fictional world functionality over the thematic. As revealed in (ii) both text functions are generally accessible unless primed with sufficient strength to make a reading based on the other text function implausible (for example, the thematic functions encoded in markers of possession). More clearly foregrounded fictional world functions are visible in $P P^{\prime} \mathrm{s}$ 
class allegory, as exemplified with friar in (iii) when the narrator describes his service to Fortune, and the resulting consequences suffered for said service:

(iii) Couetyse of yes conforted me aftur

And saide rechelesnesse reche the neuere By so thow riche were

Confesse the to som frere he shal asoilethe thus sone

How so euere thow wynne hit

For while fortune is thy frende freres wol the louye...

By wissyng of this wenche $y$ dede here wordes were so swete

Til y forzet zouthe and zorn in-to elde

And thenne was fortune my foo for al her fayre biheste

And pouerte pursuede me and potte me to be lowe

And flittyng fond $y$ the frere pat me confessede

And saide he myhte nat me assoile but y suluer hadde

To restitute resonably for al vnrihtfole wynnynge $(26,18)(12: 3-7 ; 12-18)$

Covetousness-of-eyes comforted me after

And said, 'Recklessness, never you mind as long as you're rich

Have no conscience how you came into wealth

Confess to some friar, he will soon absolve you however you won it

For while Fortune is your friend friars will love you'...

I did just as this woman advised, so sweet were her words

Until I passed youth and entered old age

And then Fortune was my foe, for all her fair promises

And poverty pursued me and put me down low.

And I found the friar who confessed me backing away

And said he could not absolve me unless I had silver

To make reasonable restitution for all wrongful earnings.

As illustrated above, the textual definiteness occurring in the friar here primes an allegorical

understanding of friar not achieved in the indefinite construction some friar. Colligation with

definiteness foregrounds the world-building functionality of the poem's class allegory to cognitively

orient focus on a specific person that stands apart from the range of other friars - both fictional and

real - manifested within the late Middle English landscape. By contrast, the underlying thematic

information surrounding friars and their evaluative significance in the late $14^{\text {th }}$ century operating as a

background conceptualisation in definite colligations of friar is functionally foregrounded in the

referent's indefinite colligations.

This foregrounding of text function is particularly visible in the binomial patterns underlying

the property allegory in PP. The grammatical and sematic similarity evidenced in these binomials

signals functional foregrounding based on the concept coordinated with the text's allegorical 
referents. For instance, the use of kind wit alongside the name of another character visible in Figure 3 with Conscience and kind wit (6) grammatically signposts a strong fictional world functionality priming the term to be read allegorically, an interpretation additionally strengthened by the capitalisation of Conscience as a proper name. The coordination of kind wit to collective nouns such as 'knighthood' and 'community' are additionally more world-building than thematic in priming understandings of two abstract human entities, one conceptually abstract while the other numerically. These binomials also foreground thematic functionality in the pairing of properties belonging (or otherwise ascribed to) demarcated entities, as seen in the description of the clergy gaining wisdom through both studying the stars and common sense (2), as well as the understanding of grace and kind wit as gifts from God and luck, respectively (5).

Functional foregrounding moreover illustrates how pragmatic meaning is extrapolated from instances characterised by ambiguity. Occurring when the underlying priming does not clearly prioritise one text function over the other, this pragmatic ambiguity makes the reader work harder to extrapolate meaning from potential allegorical constructs. This absence of functional foregrounding at the level of text is predominantly observable in $P P^{\prime}$ s property allegory, particularly in prepositional phrases such through patience and with reason. The preposition with conveys the two grammatically plausible interpretations of accompaniment or possession, with the resulting meaning based on which text function the reader chooses to cognitively foreground. Prioritising a fictional world functionality ascribes reason with allegorical personhood as an accompanying entity, while a thematic interpretation generates conceptualisation of reason as a possessed attribute. Through is similar in its potential reference to a process mitigated by (or conducted through) a physically-denoted person versus a cognitive capacity. Some of these ambiguous cases are assisted by contextual clues in the surrounding text, however this is not always the case.

This functional approach to personification allegory is most fruitfully applied in examining unusual stylised constructs within the text. As an author Langland's language is characterised by high amounts of creativity and wordplay (Pearsall, 1994: 16-17), exemplified in (iv) with the atypical 
grammatical pairing of the tangible concept cattle 'livestock', or more generally 'property', with the non-corporeal notion of kind wit (3) appearing in the teachings of imaginatif (i.e., the ability to form or construct mental images derived from memory, or the application of common sense).

(iv) Ac catel and kynde wit acombreth fol monye wo is hym pat hem weldeth but he hem wel despene (3)(14:18-9)

But wealth and kind wit encumber full many Woe to him that wields them unless he spends them well

While seemingly problematic to coordinate livestock with cognitive reasoning on a semantic level, the binomial gains meaning in the understanding that their pairing primes kind wit to be interpreted as something that can be possessed. While possible to interpret cattle literally as livestock to correspond with kind wit as another animate entity, the different levels of animacy inherent in these figures (i.e., animal versus ill-defined human person) makes it conceptually less likely than a more thematic understanding wherein the meaning of cattle is broadened to generally refer to a type of property-based wealth. In this sense the thematic signalling function associated with possession can be said to be more strongly primed in its textual use, despite the potential for extrapolated allegorical agency.

Aside from the textual encoding of animacy, the foregrounding of allegorical text function also relies on the relative commonality of these primings. Allegorical extrapolation does not occur in vacuum conditions limited to the given text (in this case, $P P$ ) but additionally integrates broader consideration of the relative frequency by which a given word, compound word, or verbal phrase is used allegorically versus non-allegorically in general language use. This frequency is experiential as well as textual, with 'the rarer sense gets primed in such a way as to ensure that their primings do not overlap with those of the most common sense' (Hoey, 2005:104). The variant, or nonprototypical, nature of personification (Stockwell, 2002: 60) in words such as truth and reason outside a limited corpus of historical literary and religious English texts results in their non-allegorical interpretation on a general basis unless otherwise signposted textually. This commonality is also 
dependent on modern versus medieval readings of allegory, with a medieval readership operating within the text's originating discourse world (Gavins, 2007: 9-10) likely possessing a stronger experiential priming (not to mention a substantively different prototypical conception system) for allegorical interpretation than the modern audiences for whom personification allegory is no longer an expected feature of modern poetic language use.

To this end, the personification allegory in $P P$ embodies a rich mixture of comparatively foregrounded levels of text functionality wherein property allegory is generally primed as a fictional world element and class allegory more generally operating as a thematic signal. This is more clearly illustrated in Figure 7 which recreates Mahlberg and McIntyre's (2011) classification system for the fictional world and thematic keywords generated in the top third of PPCorp's keyword list, using a selection of subgroups relevant to the poem. The higher amounts of property allegory evidenced here reflects the larger clustering of class allegory appearing in bottom two-thirds of the keyword list, with only friar, doctor, and reave featuring in the given selection. 
Figure 7: Recreation of world-building and thematic keyword categories in Mahlberg and Mclntyre (2011) using terms drawn from the top 285 lexical key words generated for $P P^{7}$, with all personification allegory highlighted in bold.

\section{Category}

Fictional world

Characters:

Names

Collective referents

Settings and props:

\section{Places}

Religious persons and institutions

Courts and the law

Food and drink

\section{Example key words}

conscience, Piers, mede, dowel, holy (church), Jesus, kind (wit), poverty, truth, Christ, reason, dobet, mercy, patience, Eve, dobest, pees, charity, hunger, guile, grace, Lucifer, Adam, repentance, symonye, contrition, Marie 'Mary', lechery, Abraham, faith

community, people, men, mankind

\section{Malvern}

clergy, church, friars, saints, lollards, bishops, mass, monks, Christendom

, clerks, witness(es), writ

food, drink, ale, beggars

Thematic signals

pore 'poor', soul, wicked, pardon, heaven, suffering, friar, labourers, hell, doctor, needy, pilgrims, salvation, work, reave 'reeve', darkness

The above layout effectively demonstrates the foregrounded functions for each allegorical type, however it gives the misleading impression that the poem contains comparatively little thematic signalling which, to those familiar with the text, could not be further from the truth. This categorisation is not at the exclusion of other less strongly-primed functions but rather illustrative of general trends of functional priming evidenced in the poem. While perhaps not the best visualisation 
for representing multi-functional metaphoric language, Figure 7 does suggest a level of nuance in allegorical behaviour that would otherwise be lost in broadly classifying allegory as thematic signals.

\section{Conclusion}

Through the assistance of corpus and cognitive linguistic approaches and theory, text function in personification allegory is revealed to be a complex inferential process based on degrees of primed animacy. Both text- and reader-based, animacy is conveyed through degrees of agency and definiteness (or the lack thereof) produced from the recurring lexical and grammatical patterns surrounding these allegorical referents. The strength of the semantic and grammatical encoding of animacy manifested in personification allegory in turn contributes to the priming of fictional world and thematic signals in texts like $P P$.

These functional primings have also been shown to be dependent on the type of personification-based allegory being used. The poem's class allegory, for example, broadly aligns with gambler (Mahlberg and McIntyre, 2011: 210) in perpetuating thematic concepts of significance, a function occasionally backgrounded when appearing in constructs of grammatical definiteness. By contrast, the poem's property allegory corresponds to other fictional character names like Bond, Vesper, and Le Chiffre as world-building elements unless its thematic significance is foregrounded in textual patterns signposting high levels of inanimacy. These distinctions do not preclude functional duality in personification allegory but rather highlights it, particularly in instances of ambiguity or highly stylised language use wherein the priming of one text function over the other is not so distinctly foregrounded. While not explored in depth here, the roles played by allegorical commonality and the type of reader being exposed to said constructs (medieval and modern being overgeneralisations of a broader cline of general readership) also contribute to the priming of allegorical function. 
To this end, the study presents a framework for allegorical interpretation grounded in grammatical, pragmatic, functional, and cognitive interpretation that builds on existing cognitive linguistic examinations of allegory and offers further insights to existing work in personification studies. It corroborates research linking animacy to grammatical signals in allegorical personification (i.e., Bloomfield, 1970), with the tiered animacy scale featured in Figure 6 offering an alternative paradigm for medieval scholars critical of rigid personification-based allegorical hierarchies based on grammar alone (see Scanlon, 2007). These results also have the potential to linguistically actualise the relationships Paxson (1994: 42-3) describes in the metamorphic translation of personified figures from one level of animacy to another (i.e., ideation versus topification and reification), and moreover present an interesting counterpoint to existing research on allegory in PP (e.g., Mann 2010; 2014). While developed using the data drawn from a single poetic text, it is anticipated that the results explored here operate as a microcosm reflecting the behaviour of personification-based allegory in medieval literature generally. Further study of other types of allegory (i.e., architectural), as well as close analysis of other texts containing allegory beyond $P P$, might well provide additional insight into the nature of personification allegory beyond what the present study has to offer.

\section{Declaration of Conflicting Interests}

The author declares no potential conflicts of interest with respect to the research, authorship, and/or publication of this article.

\section{Funding}

The author received no financial support for the research, authorship, and/or publication of this article. 
Notes

1. I adopt Culpeper and Kyto's (2010, citing Taavitsainen, 2001: 140) use of the term text-type to differentiate discussion of a specific, textually-based type of fictional discourse from the cultural elements of production, distribution, and consumption associated with genre.

2. Early access to (and permission to reproduce excerpts from) a digitised plain-text copy of $X$ was kindly granted by the editors at the Piers Plowman Electronic Archive.

3. To avoid conflicts of editorial intervention, all textual extracts of the poem used in this study have been drawn from the non-annotated version of PPCorp.

4. For keywords generated with a p-value of .0001 , results with a log-likelihood value over 15.13 are considered key.

5. The concordances for the allegorical referent kind were checked concurrently to confirm that no additional textual patterns were being used that did not appear for kind wit.

6. This cline mirrors the construction other gradients including but not limited to Croft's (2003: 128-9) extended animacy hierarchy and Paxson's (1994: 42-3) figural translations.

7. Number of key words chosen on an ad-hoc basis and intentionally excludes grammatical words for the sake of scope; results include words with keyness values $>30$.

\section{References}

Bart P, Calabrese M, Duggan H, Duggan G and Turville-Petre T (eds) Piers Plowman: the text of the $X$ manuscript. Unpublished digital transcription of MS Hm 143 (accessed 26 August 2015).

Bennett J (1996) Ale, beer, and brewsters in England. Oxford: University Press.

Bhatia V (1993) Analysing genre: language use in professional settings. Harlow: Longman.

Bloomfield M (1970) Essays and explorations: studies in ideas, language and literature. Cambridge: Harvard University Press.

Clarke C (2008) The allegory of landscape: land reclamation and defence at Glastonbury Abbey. In:

Crisp P (2001) Allegory: conceptual metaphor in history. Language and Literature 10(1): 5-19. 
Crisp (2008) Between extended metaphor and allegory: is blending enough? Language and Literature 17(4): 291-308.

Croft W (2003) Typology and universals. Oxford: University Press.

Culpeper J and Demmen J (2015) Keywords. In: Biber D and Reppen R (eds) The Cambridge handbook of corpus linguistics. Cambridge: University Press, pp.90-105.

Culpeper J and Kyto M (2010) Early Modern English dialogues. Cambridge: University Press. Fauconnier $\mathrm{G}$ and Turner M (2002) The way we think: conceptual blending and the mind's hidden complexities. New York: Basic Books.

Fischer-Starke B (2009) Keywords and frequent phrases of Jane Austen's Pride and Prejudice: a corpus stylistic analysis. International Journal of Corpus Linguistics 14(4): 492-523.

Foley W and Van Valin R (1985) Information packaging in the clause. Language Typology and Syntactic Description 1: 282-364.

Gavins J (2007) Text world theory: an introduction. Edinburgh: University Press. Gillespie V (2008) Afterward. In: Carr M, Clarke KP and Nievergelt M (eds) On allegory: some medieval aspects and approaches. Cambridge: Scholars Publishing, pp.231-56.

Griffiths L (1985) Personification in Piers Plowman. Cambridge: Brewer.

Halliday M and Matthiessen C (2014) An introduction to functional grammar. Abingdon: London. Hoey M (2004) The textual priming of lexis. In: Aston G, Bernardini S and Stewart D (eds) Corpora and Language Learners. Amsterdam: John Benjamins, pp.21-44.

Hoey M (2005) Lexical Priming: a new theory of words and language. London: Routledge.

Leech $\mathrm{G}$ and Short M (1981) Style in fiction: a linguistic introduction to fictional prose. Harlow: Pearson Education Ltd.

Mahlberg M (2007) Clusters, key clusters and local text functions in Dickens. Corpora, 2(1): 1-31. Mahlberg M and McIntyre D (2011). A case for corpus stylistics: Ian Fleming's Casino Royale. English Text Construction 4(2): 204-27. 
Mann, J (2010). Langland and allegory. In: Donoghue D, Simpson J and Watson N (eds) The Morton W Bloomfield lectures, 1989-2005. Kalamazoo: Medieval Institute Publications, pp.20-41.

Mann J (2014) Allegory and Piers Plowman. In: Cole A and Galloway A (eds) The Cambridge

Companion to Piers Plowman. Cambridge: University Press, pp.65-82.

Middle English Dictionary (2001). Available at: quod.lib.umich.edu/m/med/ (accessed 10 July 2017).

Paxson J (1994) The poetics of personification. Cambridge: University Press.

Pearsall D (1994) Piers Plowman: the C-text. Exeter: University Press.

Scott M (2012) WordSmith Tools, version 6. Stroud: Lexical Analysis Software.

Scott M and Tribble C (2006) Textual patterns: key words and corpus analysis in language education. Amsterdam: John Benjamins.

Stanley EG (2008) Allegory through the ages, as read mainly in England and as seen anywhere. In:

Carr M, Clarke KP and Nievergelt M (eds) On allegory: some medieval aspects and approaches. Cambridge: Scholars Publishing, pp.1-27.

Stockwell P (1992) The metaphorics of literary reading. Liverpool Papers in Language and Discourse 4: 52-80.

Stockwell P (2002) Cognitive Poetics: an introduction. London: Routledge.

Stockwell P (2009) The cognitive poetics of literary resonance. Language and Cognition, 1(1): 25-44.

Sullivan K (2014) Visibility and economy as dimensions of metaphoric language. Language and Literature 23(4): 347-368.

Taavitsainen I (2001) Changing conventions of writing: the dynamics of genres, text types, and text traditions. European Journal of English Studies, 5(2): 139-150.

Turner M (1987) Death is the mother of beauty: mind, metaphor, criticism. Chicago: University of Chicago Press.

White H (1988) Nature and salvation in Piers Plowman. Cambridge: DS Brewer.

Whitehead C (2003) Castles of the mind: a study of medieval architectural allegory. Cardiff: University of Wales Press. 
Whitman J (1987) Allegory: the dynamics of an ancient and medieval technique. Cambridge: Harvard University Press.

Yamamato M (1999) Animacy and reference: a cognitive approach to corpus linguistics. Amsterdam: John Benjamins.

Yamamoto M (2006) Agency and indefiniteness: their linguistic and cultural manifestations. Amsterdam: John Benjamins. 